GHAPTER ELEVEN

ARRIAN

T. HidBer

The future of the past: Alexander and I

Anyone who is surprised that with so many historians already in the field it should have occurred to me too to compose this history should express his surprise only after pursuing all their works and then reading mine. ${ }^{1}$

(I.praef.3)

How can you not only outdo all your numerous predecessors with their often contradictory accounts but also write the perfect and most reliable history of the most renowned and celebrated achievements and events that took place almost 500 years ago? Well, first, the greatest deeds call for the greatest narrator and the most able and sharp-witted historian. So, nobody should be left in any doubt that you are the one to do it - as Achilles had his Homer, Alexander would have his Arrian. ${ }^{2}$ Second, as for the distance between the time of narration and the time of the fabula, you have to single out the few really trustworthy sources contemporary to the events and brush off the bulk of the erroneous tradition. This is the key that gives you direct access to that remote past and brings you at eye-level with your hero. In Arrian's preface 'Ptolemy, son of Lagus, and Aristobulus, son of Aristobulus'-both not very well known as historians at the time - are identified as the only two reliable authorities, since both were not only contemporaries but also unbiased eyewitnesses of the events (I.praef.). By sticking to these two supreme sources and given his own outstanding intellectual abilities, the narrator is certain to produce the first and only account to equal

1 Translations in this contribution are all taken (with slight modifications) from Brunt 1976-1983. All dates are BC and all references to Arrian's Anabasis unless otherwise stated.

2 Cf. I.I2.I-5. 
Alexander's great deeds in literary terms. ${ }^{3}$ Therefore, the Anabasis of Alexander appears not only as a worthy monument of that unparalleled enterprise and its great leader but also provides a new and direct access to and thus revives those glorious days of the great Greek past for the benefit of both the present and future generations.

\section{On the march}

As the title - authentic or not - suggests, the subject of the Anabasis is not so much Alexander's 'life' or 'reign' but rather his great expedition. Accordingly, a preliminary narrative sets in with Alexander's accession in 336 . The dubious and much disputed circumstances of his acceding to power after his father's murder are not even mentioned (though later Alexander accuses Darius of the crime),${ }^{4}$ and the first months of preliminary diplomatic activities in Greece are only summarily dealt with in a few sentences (I.I.I-3). The marching activity starts in I.I.4: 'At the advent of spring he marched towards Thrace against the Triballi and Illyrians'. Europe, however, is swiftly left behind, and already in I.I2 the king, having crossed the Hellespont, is found paying tribute to Achilles in Troy. This is the moment for the narrator to insert his 'second preface' marking the beginning of the main story, that is, of the account of the achievements and deeds that earned Alexander fame and that the Anabasis is all about - the Persian campaign and the conquest of the East. The main story, then - virtually coinciding with the fabula, since there are hardly any external analepses or prolepses - encompasses the time span of the eleven years from Alexander's departure from Troy (334) to his death in Babylon in 323. ${ }^{5}$

As a consequence of the chosen point of departure and period of time - not immediately relevant to the narratologist, but often deplored by modern historians - , the complex and troublesome histories of the

\footnotetext{
${ }^{3}$ Cf. I.I2.5: 'That is why I think myself not unworthy of the masters of Greek speech, since my subject Alexander was among the masters of warfare'; and 7.30.3: ' $\ldots$ it was for that purpose that I embarked on this history, and like Alexander not without God's help'. As for the construction of the narrator's persona in the two prefaces cf. $S A G \mathcal{N}$ i:165-i66.

${ }^{4}$ In his letter to the great king (2.I4-5).

${ }^{5}$ A similar instance - though on a much larger scale - of the main story being preceded by a preliminary narrative can be found in Polybius $(\rightarrow)$, whose first two books function as an introduction to the main story (books $3 \mathrm{ff}$.).
} 
Macedonian dynasty and its relationship with Greece and Persia hardly get into view. Obviously, Arrian did not intend to offer an analysis either of the origins and causes of the Macedonian expedition or of its historical impact. 'The present record', the narrator points out, 'must be restricted to what appears sufficient to explain Alexander's achievements' (5.5.I). Hence, 'history' in the Anabasis is very much reduced to the reconstruction of the character and deeds of the one central figure; it proceeds, as it were, keeping its step in time to Alexander's own advances.

Not surprisingly, then, Arrian's history of Alexander's expedition may appear as what Stadter called 'a march narrative consisting of alternating marches and halts'. ${ }^{6}$ In fact, the narrative closely follows the movements of the king as he makes his way through Asia and the East. It is thus structured by the stages and halts (reception of embassies, administrative measures, and, above all, battles and sieges) of Alexander's expedition and is brought to a natural close by the death of the hero. The stages of the king's advances are often dated quite precisely. The narrative begins with the date of Alexander's accession ('in the archonship of Pythodelus at Athens', I.I.I) and his age at the time ('about twenty'). In the following, the single years of the campaign are in some cases marked by the 'advent of spring'7 — a scheme reminiscent of Thucydides $(\rightarrow)$. Exact dates indicate not only the year but also the month of the capture of Tyre ('in the archonship of Nicetus at Athens in the month Hecatombaeon', 2.24.6) and of the great victories over Darius in the battles of Issus ('So ended this battle, fought in the archonship of Athens of Nicocrates and in the month Maimacterion', 2.II.Io) and Gaugamela ('So ended this battle in the month Pyanepsion of the archonship at Athens of Aristophanes', 3.15.7 $)^{8}$ as well as of the death of Darius himself ('This was the end of Darius, when Aristophon was

${ }^{6}$ Stadter 1980: 76 .

7 I.I.4 (beginning of 335: 'at the advent of spring he marched towards Thrace'); I.I I.3 (334: 'In early spring he marched to the Hellespont'); I.24.5 (beginning of 333: 'by the time he had completed all this it was the depth of winter'); 3.6.I (beginning of 331: 'When spring began to show itself, Alexander started from Memphis for Phoenicia'); 4.7.I (beginning of 328: 'he arrived at Zariaspa, and remained there till the depth of winter was past'); 4.I8.4 (beginning of 327 : 'With the first appearance of the spring Alexander marched forward towards the Rock of Sogdiana'); 7.15.3 (beginning of 323: 'neither the wintry season nor the difficulties of the country stood in his way').

${ }^{8}$ Alexander's arrival at Thapsacus 'in the month Hecatombaeon of the year in which Aristophanes was archon at Athens' (3.7.I) is also noted, since it marks the beginning of the opening phase of the battle of Gaugamela. 
archon at Athens in the month Hecatombaeon', 3.22.2). Alexander's own end is dated by referring to the eponymous archon at Athens and to the Olympiad, which is unique in the Anabasis (contrast $\rightarrow$ Polybius) and no doubt due to the narrator closely following his source Aristobulus, thus stressing the historical importance of the date. Additionally, the king's exact age and the duration of his reign are noted according to Aristobulus:

Alexander died in the hundred and fourteenth Olympiad and the archonship of Hegesias at Athens. According to Aristobulus, he lived thirtytwo years and eight months; his reign lasted twelve years and the same eight months.

While these dates mark the main stages and achievements of Alexander's great expedition, the numerous indications of relative chronology are, perhaps, more striking because they seem to encourage the narratee to keep them in mind. Often the narrative seems to follow the advances of the king on a day-to-day basis:

From Ilium Alexander came to Arisbe, where his whole force had encamped after crossing the Hellespont; next day to Percote, the next he passed Lampsacus and camped by the river Practicus, which flows from Mount Ida and runs into the sea that lies between the Hellespont and the Black Sea. Then he reached Hermotus, passing by Colonae. ${ }^{9}$

(1.12.6)

Thus, the narratees are invited, as it were, to join the hero on his expedition, to admire his quick progress and, at the same time, the number and wealth of the cities and regions that he swiftly conquers. The presentation of an immense amount of geographical detail, such as the names of foreign rivers, mountains and towns passed and taken by Alexander, serves the same goal. At the same time, the richness in detail is intended to underscore the narrator's authority and trustworthiness.

The speed of Alexander's advances is often emphasized by mentioning the specific number of days it took him to march with his army from one place to another:

[Alexander] ... reached Sestus twenty days in all after starting from home.

(I.II.5)

9 'Next day' (tèi husteraiai) is a particularly frequent way to start off a sentence in the Anabasis; the subject almost always being Alexander himself; cf. e.g. I.7.9, I8.3, 21.5; 2.4.I; 3.18.3; 4.2.4, 26.5; 5.28.2; 6.9.1, I9.4; 7.25.3. 
After thus capturing the five cities in two days ... Alexander marched against the largest of them, Cyropolis ... ${ }^{10}$

In the record of a particular military operation chronology is often noted on an even smaller level, when the time of the day or even the watches of the night are stated. This precision is a means to create vividness in the account and to demonstrate how Alexander proceeds step by step in a way that is both daring and prudent:

About the second watch of the night they burned the wooden tower.

$(\mathrm{I} \cdot 23 \cdot 3)$

... at nightfall he himself marched with his whole force to seize the Gates again ... about midnight he was in possession of the passes once more ... just upon dawn he descended from the Gates along the road. (2.8.I-2)

A special case of the presentation of circumstantial relative chronology can be found in the chapter on Alexander's last eight days (7.25), claimed to be taken from the 'royal journals'. Although this claim seems rather dubious, the narrative, in fact, takes the form of an 'official journal' or bulletin only recording the state of health and the activities of the sick king by the day. Perhaps the very sober tone implied in such a narrative seemed to be particularly appropriate for an account of the hero's last hours. It also creates a certain distance and, as it were, gradually removes the hero both from his former life of active self-determination and from the narratee, in that Arrian's account is coming to a close.

\section{Order}

As a 'march narrative' concentrating on and closely following the proceedings and advances of the protagonist, the Anabasis clearly maintains the chronological order much more strictly than many other historiographical works. The linear pattern is preserved for the most part, and different story-lines are normally avoided; thus, the narrator explicitly excludes a report of Nearchus' voyage by sea from the Anabasis and promises to treat it on another occasion (6.28.6). This, of course, was only possible because Arrian chose to write on a topic of such a narrow scope as regards both the subject matter and the time covered. Conversely, 'universal history' encompassing thousand years and taking

10 Cf. e.g. also I.7.7, I7.ı; 3.I.I, I6.7, 20.2; 6.24.I. 
into account the fate of numerous individuals or peoples such as Cassius Dio's or Appian's Roman Histories simply could not be arranged in such a linear way. Still, even the Anabasis features various anachronies of a smaller degree.

Let us first look at analepsis. It should be said right away that narratorial analepsis does not play an important role in the Anabasis. I should like to distinguish two categories: historical digressions and closing narratorial comments.

Short digressions on the geography and topography of a particular place or town usually introduce the account of Alexander's conquest of that place. In a few instances, these initial digressions contain some information on the history of the place, for example on the origins of the strange dialect of Side (I.26.4) ${ }^{.11}$ Explanatory narratorial analepses can also be found in instances when Alexander is confronted with remains from the past, as with Gordius' famous waggon and the knot of the waggon's yoke (2.3.2).

While antecedent events are thus presented at the beginning of a particular stretch of narrative, the end of an episode is sometimes marked by the narrator's reasoning about the historical dimension of the event. By far the most elaborate sunkrisis of this sort can be found at the end of the capture of Thebes (I.9.I-8). There the narrator marks the disastrous nature of the fall (in terms of 'the size of the captured city, the sharpness of the action, and not least the general unexpectedness of the event', I.9.I) by comparing it to other defeats of the Greeks, which he briefly calls to mind (the Sicilian expedition, Aegospotami, etc.). This analepsis, as it precedes the main story of Alexander's conquests in the east, directs the narratees' attention not only back to the Greek past, but also - and perhaps even more so - raises expectations as to what is still to come in Asia.

Obituaries can be seen as a special form of closing narratorial comments. There are three instances of some length: on Darius (3.22.2-5), on Alexander's horse Bucephalas (5.19.5-6), and, of course, on Alexander himself (7.28-30). Darius' obituary, characterizing his life as 'one series of disasters, with no respite, after his accession' (3.22.3), is in fact the only, rather short, passage that allows for a closer examination of the Persian King, who otherwise remains very much a shady figure in the Anabasis. The same is even more true for Bucephalas, who

${ }^{11}$ For historical elements in geographical digressions also cf. 2.I6.I-6; 4.28; 5.I.I-2. 
acquires some prominence only with his death. Much more important is, of course, Alexander's long obituary which closes the Anabasis. This peroration does not highlight the king's achievements again, but rather offers a general view of Alexander's qualities, thereby almost adopting the form of a panegyric. ${ }^{12}$ Thus, having recounted the Anabasis, the narrator presents the sum of his hero's outstanding personality - the keystone, as it were, to the monument he so proudly erected.

As for actorial analepsis, short passages of retrospection most frequently occur in the form of messages brought to Alexander about plans or actions taken by his enemies or the people in the region which cause the king to react:

There messengers reached him with the news that Clitus, son of Bardylis, was in revolt.

Hegelochus ... reported to Alexander that the people of Tenedos had revolted from the Persians and come over to them.

$(3 \cdot 2 \cdot 3)$

Such actorial internal analepses (often anonymous) report the actions by others and constantly keep Alexander at the centre of attention. The only thing that matters is his reaction. The same holds true when envoys beg Alexander to spare their city by referring to its great history. Thus, Acuphis speaks on behalf of his city Nysa by explaining that it had been founded by Dionysus (5.I.5-6). The speech has the desired effect. Alexander in fact 'wanted to believe the tale about the wandering of Dionysus; he also wanted Nysa to be founded by Dionysus' (5.2.I).

In other instances of actorial analepsis Alexander himself can be seen looking back to events of the past. This is often the case in letters and speeches. Thus, a letter written by the Macedonian king reproaches Darius of hostile actions taken by the Persians against Greece and Macedonia as well as against Philip, Alexander's father (2.I4.4-9). This is a reply to a letter of Darius (reported only indirectly) in which the Persian king had accused Philip and Alexander of having begun the hostilities. This short passage about the contrary views of the kings is in fact the only external analepsis in the Anabasis that refers to the prehistory of Alexander's campaign, which thus remains rather obscure. Later, however, it is reported that Alexander justified the burning of the Persian palace by saying 'that he wished to punish the Persians for

\footnotetext{
12 Cf. Bosworth ig88: $135^{-1} 5^{6 .}$
} 
sacking Athens and burning the temples when they invaded Greece, and to exact retribution for all the other injuries they had done to the Greeks' (3.18.12) - a reference to the past which the narrator explicitly disapproves of in a moralizing way. ${ }^{13}$

Conversely, the past provides Alexander with examples of excellence that inspire him with emulation. Thus, he chooses the way from Ora to Pura through the desert knowing that only Semiramis and Cyrus son of Cambyses had ever managed to get through safely with an army: 'The relation of these stories to Alexander is said to have inspired him with emulation of Cyrus and Semiramis' (6.23.3). Another parallel with a great, or rather, the greatest hero of the remote past is drawn in the famous scene that introduces the 'second preface': ${ }^{14}$

Some say that Alexander crowned the tomb of Achilles, while Hephaestion, others say, placed a wreath on Patroclus' tomb; and Alexander, so the story goes, blessed Achilles for having Homer to proclaim his fame to posterity. Alexander might well have counted Achilles happy on this score, since, fortunate as Alexander was in other ways, there was a great gap left here, and Alexander's exploits were never celebrated as they deserved ... That, I declare, is why I myself have embarked on this history, not judging myself unworthy to make Alexander's deeds known to men.

(I.I2.I-2, 4)

Past, present and future are remarkably intertwined in this passage, with analepsis and (implied) prolepsis going hand in hand. Alexander is not only presented as an admirer of Achilles but also as being concerned about his future fame, even before his own great undertaking has really begun. At the same time his looking back to Homer is intended to direct the narratees' attention forward to Arrian, who seems to be prefigured in the singer of the Trojan war. And just as Achilles has always been known as a hero to men thanks to Homer, Alexander's deeds will always be known to posterity thanks to Arrian, the narrator of the Anabasis.

Whereas external actorial analepsis attached to Alexander thus most often refers to the king's own models with whom he rivals, ${ }^{15}$ internal

13 3.I8.I2: 'I too do not think that Alexander showed good sense in this action nor that he could punish Persians of a long past age'.

${ }^{14}$ For a discussion of the 'second preface' cf. Moles I985; V.J. Gray 1990; Swain 1996: 244-246; $S A G \mathcal{N}$ г:165-I66.

${ }^{15}$ Cf. also 2.7.7-8 (Alexander recalls Xenophon and his Ten Thousand as he addresses his troops at Issus); 2.I8.I (Heracles appears in a dream). 
analepsis is rather aimed at his soldiers. When on the banks of the river Hyphasis Alexander recalls the great victories and successes of the expedition so far, he unsuccessfully tries to convince his commanding officers to advance with him further east. ${ }^{16}$ Similarly, the king's address to his mutinous troops at Opis lists the achievements of the campaign in an impressive catalogue, claims that his soldiers are the real beneficiaries of these conquests, and reminds them that he had always shared their hardships. ${ }^{17}$

Actorial analepses, then, on the one hand provide some additional information, but perhaps even more importantly demonstrate Alexander's thinking in historical dimensions and his rivaling with the heroes of the remote past. They thus underscore the unique greatness of Alexander's undertaking.

I now turn to instances of prolepsis. It is characteristic of Arrian's march narrative that the next stage or destination of the campaign is repeatedly announced in a summary statement that introduces the ensuing and more detailed account (for this technique $\rightarrow$ Homer, $\rightarrow$ Pindar, $\rightarrow$ Herodotus):

Alexander now determined to make his expedition to Egypt ... (2.25.4)

After this a longing seized Alexander to pay a visit to Ammon in Libya.

Such summary way stations in the narrative call attention to the individual stages of the campaign and, thus, have an important structuring function.

More decidedly proleptic are omina or portents. Their number is, however, comparatively small in the Anabasis and the reliability of their predictive value is limited because they are interpreted by the characters, whereas the narrator, unlike, for example, Cassius Dio's, refrains from doing so. Thus, Parmenio and Alexander argue over the meaning of the sight of an eagle 'perching on the shore astern of Alexander's

\footnotetext{
${ }^{16} 5 \cdot 25 \cdot 4^{-6}$.

17 7.9-10; catalogue of achievements: 7.10.5-7. This internal analepsis, however, is preceded by a short external one referring back to the benefits and favours of Alexander's father Philip: 'Philip took you over when you were helpless vagabonds, mostly clothed in skins, feeding a few animals on the mountains ... He gave you cloaks to wear instead of skins, he brought you down from the mountains to the plains ... He made you city dwellers and established the order that comes from good laws and customs' (7.9.2). This picture of Philip as the creator of Macedonian society is certainly 'wildly inaccurate'; cf. Bosworth I988: I08-iog.
} 
ships' (I.I8.6). Parmenio thinks that it promises a successful naval campaign against the much greater Persian fleet. Alexander, however, does not follow Parmenio's interpretation of the omen but rather acts following his own 'rational' arguments (I.I8.9) and waits for a better occasion to attack the Persians on land and, of course, proves to be right (I.20.I). In another instance, Alexander, laying siege to Tyre, 'in some degree' is 'influenced' by an omen, for in a dream 'he found himself approaching the wall of Tyre, and there was Heracles, stretching out his right hand, and conducting him into the city' (2.I8.I). In fact, Aristander's interpretation of this dream-'Tyre would be taken, but with an effort, for Heracles' achievements involved effort' (2.18.2.) - turns out to be correct, in that the ensuing narrative of the siege and the final capture of the city fills no fewer than seven chapters (2.18-24).

A particularly intriguing form of prolepsis in the Anabasis (and still a matter of lively debate among historians) is the record of Alexander's plans and projects that were never realized. In his speech at the Hyphasis the Macedonian king unveils a grand scheme of conquest not only of the territories on the other side of the river, but ultimately involving the entire world (5.26.I-3). A similar plan is noted by the narrator at the beginning of book 7 (7.1.2-3). The point about the recording of these projects is obviously to demonstrate that for Alexander there were no limits at all. Thus the narrator assures us:

There is one thing I think I can assert myself, that none of Alexander's plans were small and petty and that, no matter what he had already conquered, he would not have stopped there quietly, not even if he had added Europe to Asia and the Britannic Islands to Europe, but that he would always have searched far beyond for something unknown, in competition with himself in default of any other rival.

(7.I.4)

What, if Alexander had not died as young as he did? What would the future have had in store for him? And what would the world look like now?

Finally, there are also a few instances of the narrator 'referring to his own time', for instance, when, wondering about how Alexander might have managed to cross the Indus, he turns to his own experience because his sources do not give a clue: 'the quickest way of bridging I know is the Roman use of boats, and I shall here describe it, for it merits description' (5.7.3). The following digression on that Roman military technique, then, is simply triggered by the narrator's aim to demonstrate and share his privileged knowledge with his narratees.

Overall, the sequence of the narrative is mainly chronological. In 
two cases, however, events that took place at different times are taken together in order to throw into relief a particular characteristic of the hero: chapters 4.8-I4 record examples of Alexander's arrogance and 6.26. -3 report instances of his endurance. Thus, Alexander's one flaw and one of his many outstanding qualities are brought into special prominence.

\section{Rhythm: keeping pace with the king}

As we have already seen, the narrative first sets in after the preface recounting Alexander's succession to his father's throne in 336 , but the main story does not begin until after the 'second preface', which marks the king's setting off for his grand campaign in the East in 334 . Thus, the first two years of Alexander's reign are hurried through in a rough summary of only a few chapters (I.I-II), whereas the remaining eleven years are dealt with in no fewer than 205 chapters. Although the narrative generally slows down as soon as Alexander reaches Asia, the speed still varies substantially.

Clearly, the most elaborate scenes, related in detail and at a slow pace, deal with Alexander's greatest challenges and achievements. These are, first of all, numerous battles and sieges, such as the battle at the river Granicus (I.I3-I6), the battle of Issus (2.6-II), the siege and capture of Tyre (2.I6-24), or the battle of Gaugamela (3.7-I5). These 'scenes' can further be subdivided into passages of different speed. Thus, the narrative of the battle at the Granicus is structured as follows: Alexander arrives at the river Granicus, when scouts report that Persians are drawn up for battle on the farther bank of the river; all this is reported summarily (I.I3.I-2). A debate recorded in direct speech between Parmenio and Alexander follows (I.I3.3-7) - a stretch of narrative where story-time nearly corresponds to fabula-time. Then the battle array is presented in a survey that almost takes the form of an ekphrasis; but inherent to such a pause is also a 'resultative' mode of presentation, since it implies the idea that the battle array is the result of corresponding orders and measures (2.I4.I-4). The circumstantial account of the course of the battle itself follows in chapters 2.I4.5-I5.8. Finally, the narrative speed is accelerated again as a summary is drawn with a listing of the number of the dead on both sides, the names of the fallen Persian commanders and a record of Alexander's care for the dead and the wounded (2.I6). 
Other challenges faced by Alexander and also dealt with in scenes include his injury (6.9-1I), the debate held on the banks of the Hyphasis whether to advance further east (5.25-29), and the mutiny of his troops at Opis (7.8.I-I2.4). The scene at the Hyphasis is particularly elaborated and comprises the longest debate in direct speech in the Anabasis. It thus marks the turning-point of Alexander's campaign with its reasoning about the limits of such an undertaking and the absence of any limits for the king himself.

On the whole, the halts and stages of the expedition are recorded in shorter or longer scenes, whereas the march of the army from one halt to the next is usually dealt with summarily or simply passed over in an ellipsis ('On the third day after the battle Alexander reached the Ister', I.3.I). In a few instances, however, the march itself appears as such a challenge that it is narrated in a scene of its own right. Thus, the march through the desert from Ora to the Gadrosian capital Pura (6.24-26) is recounted in detail, highlighting the hardships and sufferings of the Macedonian army. Not much attention is paid to administrative or building measures, usually treated only by way of summary.

Pauses often mark the beginning of a new stage of the campaign when the town or region that Alexander approaches next is introduced by a geographical and topographical digression that highlights the particular military challenges of the place. ${ }^{18}$ There are also a few other ekphraseis of temples or monuments such as the temple of Heracles at Tyre (2.16.I-6) or the tomb of Cyrus (6.29.4-8).

On the whole, then, the narrative's rhythm (minimizing the time between the stages of his conquests) evokes a picture of restless activity of the king, who is constantly being confronted with new challenges, always advancing and fighting his way through Asia and the eastern world.

\section{Conclusion}

The narrative's narrow scope regarding both subject matter and time covered has the effect that Alexander and his great achievements are constantly kept at the centre of interest. Due to the handling of time in the Anabasis, the hero seems to be heading from one challenge to

${ }^{18}$ Cf. e.g. I.2.I; 2.26.I; 3.23.I; 5.4.I-2. 
the next, not finding any limits to his ambitions. The narratees are, as it were, invited to join Alexander on his campaign, enter new lands, conquer city after city, advance to regions that not even Heracles or Dionysus had reached. On the whole, the portrait of a man is created who restlessly and impatiently keeps pushing further and lives a vehement life. However, the Anabasis is not a biography. Rather, it is a vivid march narrative that focuses on the hero's greatest achievements. 